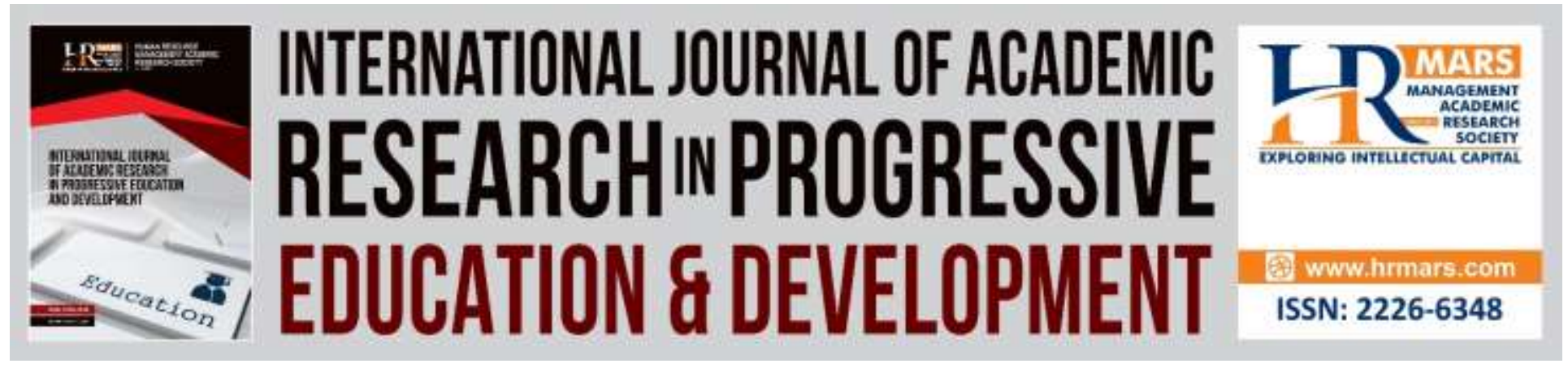

\title{
The Influence of Pre-Service Teacher's Self-efficacy on Teacher Leadership Readiness
}

\author{
Khalip Musa, Hamidah Yusof, Mohd Asri Mohd Noor, Mahaliza Mansor, \\ Masturah Zainal Abidin
}

To Link this Article: http://dx.doi.org/10.6007/IJARPED/v8-i4/6436

DOI: 10.6007/IJARPED/v8-i4/6436

Received: 10 July 2019, Revised: 18 August 2019, Accepted: 01 September 2019

Published Online: 20 September, 2019

In-Text Citation: (Musa, Yusof, Noor, Mansor, \& Abidin, 2019)

To Cite this Article: Musa, K., Yusof, H., Noor, M. A. M., Mansor, M., \& Abidin, M. Z. (2019). The Influence of PreService Teacher's Self-efficacy on Teacher Leadership Readiness. International Journal of Academic Research in Progressive Education and Development, 8(4), 66-76.

Copyright: (C) 2019 The Author(s)

Published by Human Resource Management Academic Research Society (www.hrmars.com)

This article is published under the Creative Commons Attribution (CC BY 4.0) license. Anyone may reproduce, distribute, translate and create derivative works of this article (for both commercial and non-commercial purposes), subject to full attribution to the original publication and authors. The full terms of this license may be seen

at: http://creativecommons.org/licences/by/4.0/legalcode

Vol. 8(4) 2019, Pg. 66- 76

http://hrmars.com/index.php/pages/detail/IJARPED

JOURNAL HOMEPAGE

Full Terms \& Conditions of access and use can be found at http://hrmars.com/index.php/pages/detail/publication-ethics 


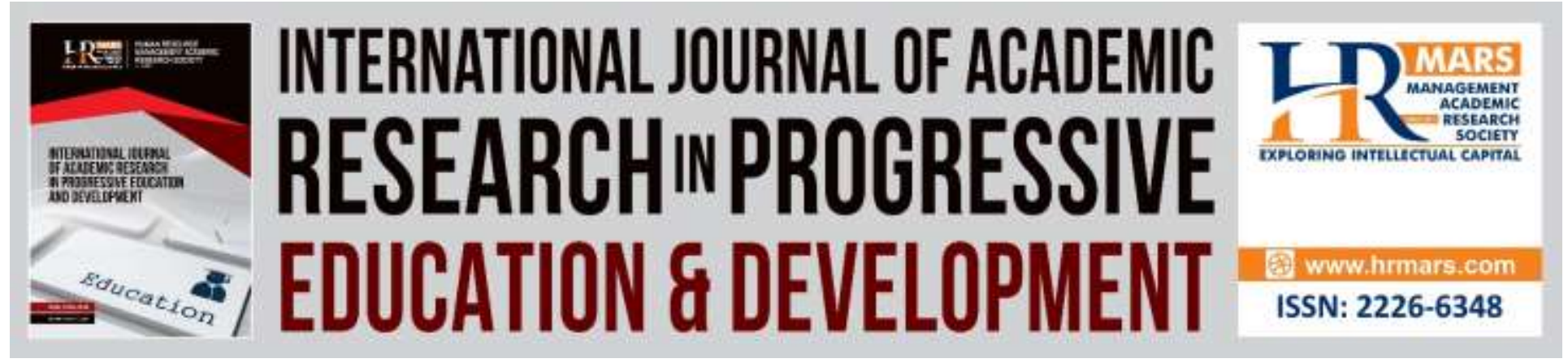

\title{
The Influence of Pre-Service Teacher's Self-efficacy on Teacher Leadership Readiness
}

\author{
Khalip Musa, Hamidah Yusof, Mohd Asri Mohd Noor, \\ Mahaliza Mansor, Masturah Zainal Abidin \\ Universiti Pendidikan Sultan Idris, Malaysia
}

\begin{abstract}
This study aimed to identify the effect of teacher self-efficacy on the readiness of teacher leadership. The study was quantitative in nature and used questionnaires as instruments in collecting data i.e. Teacher Self-Efficiency Scale and Teacher's Readiness. A total of 256 preservice teachers who were in the eighth semester at a public university were selected as a sample through a stratified sampling technique. The data were analyzed descriptively and inferential. The results showed that teachers' self efficacy $(m=6.91, s . d=0.96)$ and teacher leadership readiness $(m=3.95, s . d=0.40)$ were high. The result of the simple linear regression analysis showed that the self-efficacy of pre-service teachers influenced the readiness of teacher leadership at $R^{2}=.35, F(134.749), p<0.05$. In conclusion, the teacher's self-efficacy is an important factor in providing teacher leadership readiness. The implication of this study suggests that the teacher preparation program should consider self-efficacy as one of the essential components in its curriculum in instilling teacher leadership at an early stage.

Keywords: Pre-Service Teachers, Teacher Leadership, Teacher Self-Efficacy, Teacher Preparation Program

\section{Introduction}

The Malaysia Education Ministry has formulated an educational transformation through the Malaysia Education Blueprint (2013-2025). The main purpose of the blueprint is to provide an education system that can face the challenges of the 21st century. Among the goals of the blueprint is to improve the practice of teaching professionalism which is a major factor in determining the achievement of Malaysia Education Blueprint 2013-2025 (Malaysia Education Ministry, 2012). In the 21st century, teachers are instrumental in providing effective teaching to produce highly skilled and highly-minded students. The role of teachers in this century is more challenging when they need to develop students that meet the requirement from various professional sectors as compared to the last century which only focuses on small sectors (DarlingHammond, 2006).
\end{abstract}


Vol. 8, No. 4, 2019, E-ISSN: 2226-6348 @ 2019 HRMARS

Teacher leadership plays an important role in terms of improving students' teaching and learning, school development and teacher professional development (Fairman \& Mackenzie, 2012, Teacher Leadership Exploratory Consortium, 2010). Leadership has a great influence on schools and students when widely disseminated (Leithwood, Harris, \& Hopkins, 2008). Leadership encourages the development of the school community in terms of leadership skills and reflection, as a result, it will enhance academic achievement and produce outstanding student development. In addition, it also headed for sustainable school and community organization development (Lambert, 2003).

Teacher leadership has gone through several phases of development. According to Harris (2015), the evolution of teacher leadership takes place in three phases. The first phase of teacher leadership is that teachers hold formal responsibilities in schools such as the head of the committee related to teaching. The second phase is an expertise in teaching and has opportunities to develop teaching expertise with other teachers. The third phase of teacher leadership is that teacher leaders are seen as the center of the process of generating organizational development and change through their ability to influence other teachers as well as contributing to capacity building. Berry (2013) adds, in the face of 21st-century education, the evolution of teacher leadership is widespread. The term teacher entrepreneurs were introduced where their role beyond classroom routines through disseminating knowledge and practice to colleagues and learning community, taking administrative roles, involvement as policymakers, parents, and community leaders.

Apart from teacher leadership, teacher professional development, which is part of the leadership component of the teacher, also has positive relationships with the teacher's self-efficacy (Tschannen-Moran \& McMaster, 2009). According to Phelps (2008) in the basic teacher leadership model, efficacy is one of the values that should be in the teacher leadership model. Teachers with low efficacy cannot become a good teacher. This view supports Bandura (1997) suggestion that high-performance teachers work hard to carry out effective teaching tasks despite challenges.

In conclusion, teacher leadership and self-efficacy are regarded as the catalyst for school development based on teacher professional development and student learning improvement. Teachers with leadership and self-efficacy are capable of addressing the challenges of 21stcentury education.

\section{Research Background}

In the second wave of Malaysia Education Blueprint 2013-2025, it has given focused on transforming the pre-service teacher training that encompasses a curriculum of study. This is crucial to ensure only the best graduates are appointed as teachers. The main objective was to produce quality and competent teachers and have professional values (Ministry of Education, 2012). 
Vol. 8, No. 4, 2019, E-ISSN: 2226-6348 C 2019 HRMARS

The development of teacher leadership among pre-service teachers and in-service is crucial for improving school and student achievement (Xu \& Patmor, 2012). Teacher preparation programs focus on capacity building and build teacher talent to improve student learning. Improvement in quality research and data on the teacher preparation sector can help teachers improve their selfesteem (Gastic, 2014).

In addition, the teacher preparation program also helps pre-service teachers in readiness to play teacher leadership roles (Bond, 2011). Therefore, pre-service teachers need institutional support (school) and undergo professional development and community learning development to provide them with teacher's leader characteristics (Swanson, Elliott, \& Harmon, 2011).

The teacher preparation program plays a vital role as there is a suggestion that the responsibility of novice teachers is equal with experienced teachers. Therefore, the preparation of pre-service teachers with the knowledge, skills, and values is important in making them leaders at the early stage of their career even as novice teachers (Bond, 2011). While in school, these novice teachers are expected to have a philosophy of teacher teaching and constructive pedagogy practices, and using computer technology in teaching and learning (Riel \& Becker, 2008). The novice teacher is ready to serve with confidence when they have self-efficacy and responsibility for student learning as well as planning to continue teachers' careers (Darling-Hammond, Chung, \& Frelow, 2002). Thus, it is important for teacher preparation program to develop an understanding that the leadership development should be part of the program and not separate skills that can be developed at a later stage.

\section{Problem Statement}

The teacher preparation program has been identified as an important component in the development of teachers' self-identity and efficacy (Pendergast, Garvis \& Keogh, 2011). Teacher self-efficacy is an important criterion for improving motivation and productivity as well as a requirement within the teaching profession. Therefore, the teacher preparation program is responsible for the self-efficacy of teachers in pre-service teachers (Külekçi, 2011). Furthermore, efficacy is one of the values that should be in the leadership of the teacher. Teachers with low efficacy face difficulty in performing their task (Phelps, 2008). Therefore, self-efficacy is one of the essential elements of teachers' preparation programs.

However, pre-service teachers have encountered some problems in shaping the leadership of the teacher. Among the problems faced by pre-service teachers is the failure of effective communication. According to York-Barr and Duke (2004), communication skills are one of the requirements in teacher leadership. Pre-service teachers face communication problems with school administrators and colleagues who find it difficult to accept other teachers' reprimands and discuss with principals and concerns (Abdul, Nurul \& Shamsudin, 2015).

Although pre-service teachers were aware of the values and practices of the classroom, they were skeptical of their own ability due to lack of knowledge and skills in dealing with student diversity and education system changes (Siwatu, Chesnut, Alejandro, \& Young, 2016). In addition, 
pre-service teachers were also faced with some weaknesses in language barriers, job overlaps, weakness in reflection skills, and controlled by external factors (Hourani, 2012). They also faced personal problems that fail to manage shortcomings and solve problems wisely (Mohd, Muhammad \& Megat, 2007). In addition, they failed to emphasize the character of the teacher leadership that demonstrates self-confidence, open-minded and willing to face the risk of improving student learning (Dauksas \& White, 2010).

Problem experiences during the stage of teacher preparation program and early stage of teachers' career have resulted in teachers' motivation to decline. This condition may cause burnout among novice teachers (Gavish \& Friedman, 2010). If this situation persists, it will definitely affect the quality of teaching and learning and subsequently student academic achievement. These problems confronted by pre-service teachers and novice teachers will affect their performance in the long-term.

\section{Research Objective}

The main objective of this study is to examine the effect of self-efficacy on teacher leadership readiness among pre-service teachers.

\section{Research Question}

To what extent the effect of self-efficacy on the teacher leadership readiness among pre-service teachers?

\section{Research Framework}

This study was based on the self-efficacy of teacher leadership readiness among pre-service teachers. The teacher's self-efficacy consists of dimensions of teaching strategy, student involvement, and classroom management. The teacher's self-efficacy theory used in this study was the Master Self-Efficiency Integration Model built by Tschannen-Moran and Hoy (1998). While the teacher leadership readiness is made up of six dimensions, namely improvement in student teaching and learning, exhibiting leadership qualities and skills, involvement in organizational development, involvement in cooperative culture, involvement and co-operation with the community, and to be a reference leader. For teacher leadership theory, the researcher used a combination of five teacher leadership models to explain the six principles contained in the Teacher Leadership Model. The combined models are from Fairman and Mackenzie (2012), Teacher Leader Exploratory Consortium (2012), Katzenmeyer and Moller (2009), Riel and Becker (2008), and Grant (2006).

\section{Literature Review}

Teacher self-efficacy influenced the effectiveness of teaching and learning (Gibson \& Dembo, 1984). There were several definitions of self-efficacy of teachers that each lead to the effectiveness of teaching. Bandura (1997) defined the meaning of teachers' self-efficacy as a person's beliefs about his ability to carry out an action in teaching that can support student academic progress. Tschannen-Moran and Hoy (1998) expressed the purpose of teacher's selfefficacy as a teacher's belief in his ability to manage and implement the necessary actions, 
especially teaching successfully in certain contexts. To explain the meaning of leadership readiness, Katzenmeyer and Moller (2009) stated the readiness of teacher leadership is a situation in which teachers are aware of their potential to lead and cherish as leaders. Teachers who are willing to become teacher leaders are teachers who recognize their potential to become leaders and understand the criteria as teacher leaders and support the development of teacher leadership among colleagues. There are three criteria for identifying potential teacher leaders i.e. competent, credible and approachable. The readiness of teacher leadership is not limited to experienced teachers, but it also to pre-service teachers.

Helterbran (2010) explained, in nurturing teachers leadership among pre-service teachers, there were some considerations should be taken into account. One was to emphasize teacher leadership during the recruitment process and induction programs. This statement also supported by Sherrill (2011) which supports the effort to apply teacher leadership into the teacher preparation program. Additionally, according to Ado (2016), pre-service teachers need to have the concept of teacher leadership since the beginning of pre-service in teacher training. Failure to inculcate the concept of teacher leadership at the beginning will affect pre-service teachers performance.

In the context of teachers' self-efficacy, teachers' confidence affects the learning environment created and students' academic progress (Bandura, 1993). This is because, if the teacher believes in their ability, they can encourage student learning through cognitive experience and development (Bandura, 1997; Matarid, Sobh, \& Ahmed, (2018). According to Bandura (1997), pre-service teachers with strong teacher efficacy carry out excellent tasks through lesson planning, group discussion, and managing classes during teaching practice.

Reeves and Lowenhaupt (2016); Sangakala, Ahmed, \& Pahi, (2016) study of pre-service teachers from primary, secondary school, special education schools, and other teacher preparation programs found that the majority of their aspirations for a leadership role after five years were still the role of class teachers. In addition, his findings show that teachers' motivation, altruistic motivation, are the keys rationale of pre-service teachers entering the teaching profession because they want to help others, especially children/teens and dreams to improve society. In the context of leadership, there is a positive link between aspirations to become expert teachers with motivation. According to Bandura (1982), self-efficacy affects motivation.

\section{Research Methodology}

This study used quantitative design and a regression analysis to achieve the study objectives. The survey method was used as the main method in obtaining information on the readiness of teacher leadership and self-efficacy among pre-service teachers. The population of the study consists of 363 pre-service teachers from seven educational programs in Bachelor of Education degree and have attended teaching practicum in schools. The sample size was 187 and it was determined by using Krejcie and Morgan's (1970) sampling table. 
Vol. 8, No. 4, 2019, E-ISSN: 2226-6348 @ 2019 HRMARS

To determine the number of samples comprising the seven educational programs, the researcher used the stratified sampling method according to the program. Simple random sampling technique was used in each program to ensure bias does not exist in this study. Random sample selection will give the same probabilities to students in each program to be a sample (Creswell, 2014). Instruments in this study consist of 77 items i.e. demographic information, Self-Efficiency Scale of Teacher and Readiness of Teacher Leadership.

\section{Data Analysis and Research Output}

Overall, the teachers' self-efficacy was high with a mean score of 6.91 and the standard deviation of 0.957 . The teachers' leadership readiness was also high with a mean score of 3.95 and the standard deviation of 0.404 is high. Table 1 shows the mean score and standard deviation for teachers' self-efficacy level and teachers' leadership readiness. In conclusion, descriptive analysis shows the level of self-efficacy and teacher's leadership readiness at a high level.

Table 1: Level of Teacher Self-Efficacy and Leadership Readiness

\begin{tabular}{|l|l|l|l|l|l|}
\hline No. & Dimension & N & Mean & S.D & Level \\
\hline 1 & Teacher self-efficacy & 256 & 6.91 & 0.957 & High \\
\hline 2 & Teacher leadership readiness & 256 & 3.95 & 0.404 & High \\
\hline
\end{tabular}

The results of the simple regression analysis show that $\mathrm{H}_{0}$ was rejected at a significant level of 0.05 . The simple regression analysis using the simultaneous method (Enter) shows that the selfefficacy of the teacher has influenced $34.7 \%$ of variance changes in the readiness of teacher leadership. Table 2 shows the results of simple linear regression analysis between teacher selfefficacy and teacher leadership readiness.

\section{Table 2: Regression Analysis}

\begin{tabular}{|l|l|l|l|l|l|}
\hline Variable & $\mathrm{B}$ & Std. Err. & Beta & $\mathrm{t}$ & Sig \\
\hline Intercept & 2.235 & .150 & & 14.936 & .000 \\
\hline Self-efficacy & .249 & .021 & .589 & 11.609 & .000 \\
\hline $\mathrm{R}=0.589$ & $\mathrm{R}^{2}=0.347$ & Adj. RSqr $=0.344$ & $\mathrm{~F}=134.749$ & & \\
\hline
\end{tabular}

The result of the simple linear regression analysis showed that the self-efficacy of pre-service teachers influenced the readiness of teacher leadership at $R^{2}=.35, F(134.749), p<0.05$. In conclusion, teacher's self-efficacy is an important factor in providing teacher leadership readiness. 
Vol. 8, No. 4, 2019, E-ISSN: 2226-6348 @ 2019 HRMARS

\section{Discussion and Research Implication}

The regression analysis has shown that self-efficacy of teachers influences the readiness of teacher leadership among pre-service teachers significantly. According to Xu and Patmor (2012) to nurture the leadership among pre-service teachers, they need to shift their views from students' perspective to teacher's perspective during training programs so they can embrace teacher leadership responsibilities. Therefore, teacher training programs should provide leadership experiential learning to the student.

In addition, in the study of Lasauskiene and Rauduvaite (2015), he explained that the formation of future teacher leaders in pre-service teachers requires some approaches. Among these, the formation of true student emotion by strengthening the confidence level of pre-service teachers. Bandura (1997) stated that emotional states influence the individual's ability to achieve certain achievements. In addition, the study of Guskey (1984), and Giles, Byrd, Bendolph and Boylan (2016), has explained that teachers who confident in carrying out the teaching have high selfefficacy. Confidence in pre-service teachers can influence their role in teacher leadership such as making improvements in teaching and learning, engaging with staff development programs, and establishing good relationships with colleagues and students.

In relation, this study suggests that teacher leadership readiness among pre-service teachers is crucial in preparing them to be teacher's leader. This role becomes a necessity in facing new challenges in teaching and learning where teacher teamwork and students' improvement and achievement become a central focus. Teacher leadership is not just applied to senior teachers but should be nurtured among teacher trainees. This study supports Bond (2011), that the teacher leadership should be introduced at the university level by forming the knowledge and skills of teacher leadership. These will help pre-service teachers deliver their task within such condition. In addition, schools should encourage cooperation culture among teachers' colleagues through mentoring and sharing responsibilities.

\section{Conclusion}

Performance among pre-service teachers during practicum is closely linked to their self efficacy. Those who have positive self-efficacy are able to provide a better teaching and learning experience. Therefore, the teaching training programs should focus on the construction of this element in their curriculum. Positive self-efficacy will help the development of teacher leadership readiness among pre-service teachers. This early readiness will enable novice teachers to play an equally important role with experienced teachers in contributing to the effectiveness of teaching and learning and schools.

\section{Acknowledgement}

This research was supported by Malaysia Education Ministry under Niche Research Grant Scheme for Development of Teacher Education Model for Preparing Quality Teacher for the Future, 2013-2018. 
INTERNATIONAL JOURNAL OF ACADEMIC RESEARCH IN PROGRESSIVE EDUCATION AND DEVELOPMENT

Vol. 8, No. 4, 2019, E-ISSN: 2226-6348 ㄷ 2019 HRMARS

\section{Corresponding Author}

Hamidah Yusof

Faculty of Management and Economics, Universiti Pendidikan Sultan Idris, Malaysia

Email: hamidah.yusof@fpe.upsi.edu.my

\section{References}

Sangakala, M., Ahmed, U., \& Pahi, M. H. (2016). Empirical investigating on the role of supervisor support, job clarity, employee training and performance appraisal in addressing job satisfaction of nurses. International Business Management, 10(23), 5481-5486.

Matarid, N. M., Sobh, O. S., \& Ahmed, U. (2018). The Impact of Organizational Justice and Demographics on Faculty Retention in Bahrain. Le travail humain, (3).

Abdul, R. J., Nurul, N. R., \& Shamsudin, O. (2015). Keupayaan guru pelatih terhadap pelaksanaan aktiviti semasa latihan mengajar dalam pembentukan guru novis. Jurnal Pendidikan Malaysia, 40(1), 75-81.

Ado, K. (2016). From Pre-Service to Teacher Leader: The Early Development of Teacher Leaders. Issues in Teacher Education, 25(1), 3-21.

Bandura, A. (1982). Self-efficacy mechanism in human agency. American Psychologist, 37(2), 122147. http://dx.doi.org/10.1037/0003-066X.37.2.122

Bandura, A. (1993). Perceived self-efficacy in cognitive development and functioning. Educational Psychologist, 28, 117-148.

Bandura, A. (1997). Self-Efficacy: The Exercise of Control. Worth Publisher.

Berry, B. (2013). Teacherpreneurs: A bold brand of teacher leadership for 21st-Century teaching and learning. Science, 340(19), 309-310.

Bond, N. (2011). Preparing preservice teachers to become teacher leaders preparing preservice teachers to become teacher leaders. The Educational Forum, 75(4), 280-297.

Creswell, J. W. (2014). Research design: qualitative, quantitative, and mixed methods approaches. 4th ed. Thousand Oaks, California: SAGE Publications.

Darling-Hammond, L., Chung, R., \& Frelow, F. (2002). Variation in Teacher Preparation: How Well Do Different Pathways Prepare Teachers to Teach? Journal of Teacher Education, 53(4), 286-302.

Darling-Hammond, L. (2006). Constructing 21st-Century teacher education. Journal of Teacher Education, 57(3), 300-314.

Dauksas, L., \& White, J. (2010). Should I stay or should I go? How teacher leadership can improve teacher retention. Journal of Scholarship and Practice, 7(2), 27-32.

Fairman, J. C., \& Mackenzie, S. V. (2012). Spheres of teacher leadership action for learning. Professional Development in Education, 38(2), 229-246.

Helterbran, V. R. (2010). Teacher Leadership: Overcoming "I Am Just a Teacher" Syndrome Education, 131(2), 363-371.

Gastic, B. (2014). Closing the opportunity gap: Preparing the next generation of effective teachers. In F. M. Hess \& M. Q. McShane (Eds.), Teacher Quality 2.0: Toward a New Era in Education Reform. Harvard Educational Publishing Group.

Gavish, B., \& Friedman, I. A. (2010). Novice teachers' experience of teaching: A dynamic aspect of burnout. Social Psychology of Education, 13(2), 141-167. 
INTERNATIONAL JOURNAL OF ACADEMIC RESEARCH IN PROGRESSIVE EDUCATION AND DEVELOPMENT

Vol. 8, No. 4, 2019, E-ISSN: 2226-6348 @ 2019 HRMARS

Gibson, S., \& Dembo, M. H. (1984). Teacher efficacy: A construct validation. Journal of Educational Psychology, 76(4), 569-582.

Guskey, T. R. (1984). The influence of change in instructional effectiveness upon the affective characteristics of teachers. American Educational Research Journal, 21, 245-259

Giles, R. M., Kelly, O. B., Bendolph, A., \& Boylan, M. (2016) An investigation of elementary preservice teachers' self-efficacy for teaching mathematics, Cogent Education, 3:1, DOI: 10.1080/2331186X.2016.1160523

Grant, C. (2006). Emerging Voices on Teacher Leadership: Some South African Views. Educational Management Administration \& Leadership, 34 (4), 511-532. https://doi.org/10.1177/1741143206068215

Harris, A. (2015). Teacher Leadership. International Encyclopedia of the Social \& Behavioral Sciences, 24, 60-63.

Helterbran, V. R. (2010). Teacher Leadership: Overcoming "I Am Just a Teacher" Syndrome. Education, 131(2), 363-371.

Hourani, B. R. (2012). Pre-service Teachers' Reflection: Perception, Preparedness and Challenges. Reflective Practice, 14(1), 12-30.

Katzenmeyer, M., \& Moller, G. (2009). Awakening the Sleeping Giant: Helping Teachers Develop as Leaders (3rd ed.). Carlifornia: Crowin Press.

Krejcie, R. V., \& Morgan, D. W. (1970). Determining Sample Size for Research Activities. Educational and Psychological Measurement, 30, 607-610

Külekçi, G. (2011). A study on pre-service English teachers' self-efficacy beliefs depending on some variables. International Online Journal of Educational Sciences, 3(1), 245-260.

Lambert, L. (2003). Leadership redefined: An evocative context for teacher leadership Leadership Redefined : an evocative context for teacher leadership. School Leadership \& Management, 23(4)(October), 421-430.

Leithwood, K., Harris, A., \& Hopkins, D. (2008). Seven strong claims about successful school leadership. School Leadership \& Management, 28(1), 27-42.

Lasauskiene, J., \& Rauduvaite, A. (2015). Stimulation of Pre-service Music Teachers' Leadership Through Musical Activities. Procedia-Social and Behavioral Sciences, 182, 301-306.

Malaysia Education Ministry. (2012). Malaysia Education Blueprint 2013-2025. Putrajaya.

Mohd, Z. A. H., Muhammad, R. H., \& Megat, A. Z. Z. (2007). Harapan dan keresahan bakal guru pelatih dalam praktikum latihan mengajar. Seminar Penyelidikan Pendidikan Institut Perguruan Batu Lintang, 1-8.

Pendergast, D., Garvis, S., \& Keogh, J. (2011). Pre-service student-teacher self-efficacy beliefs: An insight into the making of teachers. Australian Journal of Teacher Education, 36(12), 4658.

Phelps, P. H. (2008). Helping Teachers Become Leaders. The Clearing House: A Journal of Educational Strategies, Issues and Ideas, 81(3), 119-122.

Reeves, T. D., \& Lowenhaupt, R. J. (2016). Teachers as leaders: Pre-service teachers' aspirations and motivations. Teaching and Teacher Education, 57, 176-187.

https://doi.org/10.1016/J.TATE.2016.03.011 
Riel, M., \& Becker, H. J. (2008). Characteristic of teacher leaders for information and communication technology. International Handbook of Information Technology in Primary and Secondary Education, 397-417.

Sherrill, J. (2011). Chapter Twenty-Two: Preparing Teachers for Leadership Roles in the 21st Century. Counterpoints, 408, 221-228. Retrieved from http://www.jstor.org/stable/42981283

Siwatu, K. O., Chesnut, S. R., Alejandro, A. Y., \& Young, H. A. (2016). Examining Preservice Teachers' Culturally Responsive Teaching Self-Efficacy Doubts. The Teacher Educator, 51(4), 277-296.

Swanson, J., Elliott, K., \& Harmon, J. (2011). Teacher leader stories: The power of case methods. California: Corwin Press.

Teacher Leader Exploratory Consortium. (2012). Teacher Leader Model Standards.

Tschannen-Moran, M., \& McMaster, P. (2009). Sources of self-efficacy: Four professional development formats and their relationship to self-efficacy and implementation of a new teaching strategy. The Elementary School Journal, 110(2), 228-245.

Tschannen-Moran, M., \& Hoy, A. W. (1998). Teacher efficacy: Its meaning and measure. Review of Educational Research, 68(2), 202-248.

$\mathrm{Xu}, \mathrm{Y}$., \& Patmor, G. (2012). Fostering leadership skills in pre-service teachers. International Journal of Teaching and Learning in Higher Education, 24(2), 252-256.

York-Barr, J., \& Duke, K. (2004). What do we know about teacher leadership? Findings from two decades of scholarship. Review of Educational Research, 74(3), 255-316. 